\title{
DISPUTE INTERNATIONAL BETWEEN INDONESIA AND MALAYSIA SEIZE ON SIPADAN AND LINGITAN ISLAND
}

\author{
Nur Fareha Binti Mohamad Zukri \\ International Student of Sultan Agung Islamic University Semarang \\ farehazukri@gmail.com \\ Ong Argo Victoria \\ International Islamic University Malaysia \\ argovictoriaupin@gmail.com \\ Fadli Eko Apriliyanto \\ Sultan Agung Islamic University Semarang \\ padkay83@gmail.com
}

\begin{abstract}
In 1998 the issue of Sipadan and Ligitan dispute brought to the ICJ, later in the day Tuesday, December 17, 2002 IC] issued a decision on the sovereignty dispute case of Sipadan-Ligatan between Indonesia and Malaysia. As a result, in the voting at the institution, Malaysia won by 16 judges, while only one person who sided with Indonesia. Of the 17 judges, 15 are permanent judges of MI, while one judge is an option Malaysia and another selected by Indonesia. Victory Malaysia, therefore under consideration effectivity (Without deciding on the question of territorial waters and maritime boundaries), the British (colonizers Malaysia) has made a real administrative action in the form of the issuance of bird wildlife protection ordinance, a tax levied against turtle egg collection since 1930, and the operation of the lighthouse since the 1960s an. Meanwhile, Malaysia's tourism activities do not be a consideration, as well as the refusal is based on chain of title (a proprietary suite of Sultan of Sulu) but failed to demarcate the sea border between Malaysia and Indonesia in Makassar strait.
\end{abstract}

Keywords: Dispute; International; Island.

\section{A. INTRODUCTION}

Sea is one of the natural resources that can be utilized by humans through the country to meet and realize the people's welfare. In ancient times the sea can be used by any State that wants to use it, but with the legal regime of the sea by UNCLOS in 1982 which contains various rules and restrictions for each country to exploit the natural resources in the form of sea ${ }^{1}$.

1 Taufik Abdullah, Towards a National Historical Writing at the Local Level, ed, Press UGM, Yogyakarta, 2005 
The struggle for Sipadan and Ligitan islands between Indonesia and Malaysia because Malaysia considers Sipadan and Ligitan is owned by Malaysian origin is Sipadan and Ligitan were split over treaty convention in 1891, ie between the Dutch state and the United Kingdom.

But here the British who eventually exploiting Sipadan and Ligitan to establish turtle breeding activities and exploitation of natural resources and to build a resort in 1988. Along with independent of Malaysia. What is owned by the British considered by Malaysia as belonging to Malaysia because the British give to the government of Malaysia area ${ }^{2}$.

Malaysia assume that what the British gave was hers, and Malaysia continued on turtle breeding, natural resources, and build the resort in 1988. However, this has led to controversy between the Malaysia and Indonesia. Indonesia claims that Sipadan and Ligitan is an area of Indonesian sovereignty, does not belong to Malaysia. Economically, Malaysia has been doing construction on the two islands considers that the right to have the Sipadan and Ligitan is right Malaysia this problem could not be resolved by the two parties so that these two islands dispute is brought to the International Court.

In the international tribunal, both parties, both Indonesia and Malaysia to make efforts persuasive and convincing international court that they are entitled to have two islands, the ICJ ruled that Malaysia is entitled to ownership of the islands of Sipadan and Ligitan kasus will be discussed about the seizure of the island with neighboring countries, namely Malaysia, which remains a region with Indonesia.

Conflict of Sipadan and Ligitan are Indonesia and Malaysia dispute over the ownership of the two islands in the Strait of Makassar is the island of Sipadan (area: 50,000 meter ${ }^{2}$ ) with coordinates: $4^{\circ} 6^{\prime} 52.86^{\prime \prime} \mathrm{LU} 118^{\circ} 37^{\prime}$ 43.52"BT and Ligitan islands (area: 18,000 meters ${ }^{2}$ ) With coordinates: $4^{\circ} 9^{\prime} \mathrm{LU} 118^{\circ} 53^{\prime} \mathrm{BT}$. Attitude Indonesia originally wanted to bring this issue through the ASEAN High Council but finally agreed to resolve this dispute through the International Court of law for that we need a political system that governs the relationship between the countries adjacent above the surface of the earth.

The political system is called geopolitics that is absolutely owned and implemented by every country in the vicinity including Indonesia must have a suitable geopolitical system applied with the unique archipelagic condition and location of Geography. 73 Indonesian state above the surface of the planet Earth is nothing but a geopolitical Indonesian archipelago insight. Insights archipelago does not contain elements of violence, perspective Indonesian people about themselves and their environment based on the idea of national which is based on Pancasila and the 1945 Constitution which is the aspiration of the nation of Indonesia's independence, sovereignty, and dignity and animating system life and acts of discretion in achieving national goal

In this case as well Indonesian citizens who apply geopolitical must take to preserve and maintain the territorial integrity of the country and could not be denied in Indonesia

2 Adolf Huala, International Dispute Resolution Law, Sinar Grafika Jakarta, 2006. 
revolving conflicts over Sipadan and Ligitan islands with neighboring countries, namely Malaysia. Actually, between Indonesia and Malaysia are not only was a struggle for the island or area of the country alone but ever there was a struggle of culture, typical food, folk songs and it continues to run in a struggle for the island is one of the only islands of Sipadan and Ligitan.

\section{B. DISCUSSION}

\section{Completion of Sipadan and Ligitan case appropriate International Legal Procedures}

Indonesia initially only wanted to resolve this conflict through ASEAN, and always refused to memmbawa the issue to the International Court of Justice (ICJ) softened and changed from the initial establishment. At that time Indonesia led by President Suharto held a meeting with Malaysian Prime Minister Mahathir in 1996, and they make a deal "Final and Binding" who agreed to take the case to the ICJ and Indonesia ratified the agreement dated December 29, 1997 by Presidential Decree Number 49 Of 1997. Then Malaysia participated ratified on 19 November 1997. ${ }^{3}$ Indonesia also has some course of this case. One is the ASEAN Way where the highest priority on peaceful conflict resolution. Also on view through economic factors Malaysian investment in Indonesia is quite large because in 1997-2004 reached 67 trillion. If at that time relations between Indonesia and Malaysia worsens it will be detrimental to Indonesia itself. Coupled with the number of Indonesian Workers (TKI) that education is less about 500 thousand people. ${ }^{4}$

But in the end December 17, 2002 Decision of the International Court of Justice (ICJ) gives the right to sovereignty over Sipadan and Pulau region Ligitan to Malaysia. There are several possible reasons why Malaysia who won a case annexation by Indonesia, namely:

a. Carelessness Indonesia in terms of not paying attention to the development of its lands.

b. Lack of coordination between agencies or departments related to the management of these two islands. International Court of Justice made the decision to give priority to Level Analysis States: continuous presence, effective occupation, and ecology preservation

With the decision that has been an absolute given by the ICJ, the islands of Sipadan and Ligitan then Malaysia has the right region and increasing the area of

3 Adolf Huala, International Dispute Resolution Law, Sinar Grafika Jakarta, 2006.

4 Booth, Ken, Security in Anarchy: Utopian Realism in Theory and Practice, International Affairs (Royal Institute of International Affairs 1944), Volume 67 No. 3, July 1991 
teritotialnya and of course Malaysia has the right to manage all the natural resources that exist on the island of Sipadan and Ligitan and everything contained in the sea. ${ }^{5}$

In analyzing the case of disputes Sipadan and Ligitan islands, I use the geopolitical theory presented by Peter Wallensteen in his book entitled "Understanding Conflict Resolution" he said, "Geopolitics as we have defined it, is concerned with territories of particular interest. In its original form, dealing with major powers, particular regions would gain eminence in global strategies "case between Indonesia and Malaysia immediately submit the conflict between them both to the International Court. ${ }^{6}$

It uses the resolution of the conflict settlement by means of arbitration. According to Black's Law Dictionary "Arbitration an arrangement for taking an abiding by the judgment of selected persons in some disputed matter, instead of carrying it to establish Tribunals of justice, and is intended to avoid the formalities, the delay, the expense and vexation of ordinary litigation. "

Through various meetings in several years, the two sides concluded this dispute difficult to resolve bilaterally Therefore, both parties agreed to submit this resolution to the International Court of Justice to sign the "Treaty Special for submission to the International Court of Justice in a dispute between Indonesia and Malaysia regarding sovereignty over Ligitan and Sipdan, "in Kuala Lumpur on May 31, 1997.

Through this joint letter agreement dispute case is submitted to the International Court in The Hague on 2 November 1998 Both sides believe the court will take a fair decision about who is sovereign over Ligitan and Sipadan sovereignty, based on the evidence available. Indonesia basing sovereignty over the islands, according to Article IV of the 1891 Convention between the Netherlands and the United Kingdom. ${ }^{8}$

While Malaysia basing its ownership by two grooves that groove Sultan of SuluSpanish-US-British-Malaysia and the flow of the Sultan of Sulu-Den \& amp; OverbeckBNBC-Malaysia. Malaysia also holds that its sovereignty over those islands by the fact that the British and later by Malaysia since 1878 peacefully continuously manage both islands. In front of the International Court, to prove his claim, the parties must fulfill procedures, among others, said the written submissions and memory, memory and replict appeal.

Until it enters the delivery phase of the oral submissions. Oral submissions divided into two: the first round on 3rd and June 4th, 2002 Indonesia presented his

5 Peter Wallensteen. Understanding Conflict Resolution. (London: Sage Publications), 2002 page. 96

6 Pendekta 2006, " International Studies Against Against Human Rights " , , Journal of Legal Studies State University of Semarang Volume 2 \# 2, July-December, 2008.

7 Taufik Abdullah, Towards a National Historical Writing at the Local Level, ed, Press UGM, Yogyakarta, 2005 8 Ibid. 
defense in open hearings. Following Malaysia on the 6th and 7th of June. Being a second round on June 10 for Indonesia and Malaysia on June 12 answer.

Regarding ways to express the case, the deadline for submission of written pleadings and oral contained in the Statute of the ICJ. The oral submissions, as written defending the continuation of which ended in March 2000, will last until June 12, 2002 the Government of Indonesia is of the opinion that the islands of Sipadan and Ligitan island belonging to Indonesia.

Indonesia basing sovereignty over the islands, according to Article IV of the 1891 Convention between the Netherlands and the United Kingdom. While Malaysia basing its ownership by two grooves that groove Sultan of Sulu-Spanish-US-BritishMalaysia and the flow of the Sultan of Sulu-Den \& amp; Overbeck-BNBC-Malaysia.

On December 17, 2002, the International Court of Justice in The Hague decided, Sipadan and Ligitan is based on the fact the region Malaysia, UK and Malaysia considered to have carried out the sovereignty of a more "effective" on the island before 1969. Indonesia respects his decision, especially since Article 5 Approval of 1997 expressly states that both parties agree to accept the judgment of the Court given pursuant to this Special Agreement as and binding upon th.

In 1998 the issue of Sipadan and Ligitan dispute brought to the ICJ, later in the day Tuesday, December 17, 2002 ICJ. The detailed chronology of Sipadan and Ligitan case can be seen in the table below ${ }^{9}$ :

\begin{tabular}{|c|c|}
\hline Year & vent \\
\hline 1969 & $\begin{array}{l}\text { Dispute over Sipadan and Ligitan islands first appeared in the negotiations } \\
\text { on the continental shelf boundary between Indonesia and Malaysia in } \\
\text { Kuala Lumpur ( } 9 \text { to } 12 \text { September 1969). Agreed Outcome: both parties } \\
\text { to refrain from doing activities that are related to both the island until the } \\
\text { settlement of disputes. }\end{array}$ \\
\hline 1970 & $\begin{array}{l}\text { laysia undertake unilateral actions by publishing a map that includes } \\
\text { two islands into the national territory, and a few years later did the } \\
\text { nstruction and management of tourist facilities on both islands. }\end{array}$ \\
\hline 1985 & $\begin{array}{l}\text { Discussion of the dispute by the President Soeharto and Prime Minister of } \\
\text { Malaysia Mahathir Mohammad in Yogyakarta, } 1989 \text {. The conclusion: a } \\
\text { dispute over two islands is difficult to be solved within the framework of } \\
\text { bilateral negotiations. }\end{array}$ \\
\hline 19 & $\begin{array}{l}\text { Both sides agreed to submit the settlement of the dispute to the } \\
\text { International Court of Justice to sign the document "Special Agreement for } \\
\text { the Submission to the International Court of Justice on the Dispute } \\
\text { between Indonesian and Malaysia concerning the Sovereignty over }\end{array}$ \\
\hline
\end{tabular}

9, Daniel Dhakidae, Relationship Love - Hate between Indonesia and Malaysia, Prisma, Jakarta, 2009 


\begin{tabular}{|l|l|}
\hline 1998 & Ligitan and Sipadan" in Kuala Lumpur on 31 May 1997. \\
\hline 2000 & $\begin{array}{l}\text { On November 2, 1998, a special deal that was signed was then formally } \\
\text { submitted to the International Court of Justice, through a "joint letter" or } \\
\text { notifications together. }\end{array}$ \\
\hline 2002 & $\begin{array}{l}\text { Written argumentation process ( "written pleadings") on both sides is } \\
\text { considered completed by the end of March } 2000 \text { at the International } \\
\text { Court. The written arguments consist of the delivery of "memorial", } \\
\text { "counter memorial", and "reply" to the International Court. }\end{array}$ \\
\hline $\begin{array}{l}\text { Dispute resolution process Sipadan and Ligitan in the International Court } \\
\text { entered its final stages, the process of oral argument ( "oral hearing"), } \\
\text { which took place from 3 to 12 June 2002. On that occasion, Foreign } \\
\text { Minister Hassan Wirajuda of Indonesia as the holder's attorney, argues } \\
\text { verbal ( "agent's speech"), which is then followed by a presentation } \\
\text { delivered juridical arguments RI lawyer Tim. International Court then } \\
\text { stated that the final decision on the dispute will be set in December 2002. }\end{array}$ \\
$\begin{array}{l}\text { On 17 December 2002, the International Court of Justice in The Hague set } \\
\text { the Sipadan and Ligitan islands to be part of the sovereign territory of the } \\
\text { Kingdom of Malaysia on the basis of "effectiveness" because Malaysia has } \\
\text { made an effort the administration and management of nature } \\
\text { conservation on the islands. }\end{array}$ \\
\hline
\end{tabular}

\section{Cause of Indonesia Lose in International Law Dispute}

The decision on Sipadan-Ligitan island sovereignty dispute between Indonesia and Malaysia. As a result, in the voting at the institution, Malaysia won by 16 judges, while only one person who sided with Indonesia. Of the 17 judges, 15 are permanent judges of MI, while one judge is an option Malaysia and another selected by Indonesia.

Victory of Malaysia, therefore under consideration effectivity (without deciding on the question of territorial waters and maritime boundaries), the British government (invaders Malaysia) has conducted administrative action substantially in the form of the issuance of the ordinance the protection of birds, levy a tax on the collection of turtle eggs since 1930, and the operation of the lighthouse since the 1960s.

Meanwhile, Malaysia's tourism activities do not be a consideration, as well as the refusal is based on chain of title (a proprietary suite of Sultan of Sulu) but failed to demarcate the sea border between Malaysia and Indonesia in Makassar strait.

Here are three points of the Principles of International Court of Justice ruling on the dispute over Ligitan-Sipadan island, namely:

a. Reject the Malaysian argument that the disputed islands ever become part of the area acquired Malaysia based private management contract with the Sultan of 
Sulu-Overbeck Sen / BNBC / English / Malaysia. The Court also rejected the argument Malaysia that the two islands included in the Sulu / Spanish / US / UK are then handed over to the Malaysian based terori ownership chain (Chain of Title Theory). According to the Court neither legal documents or evidence submitted Malaysia based on the argument of the transfer of sovereignty in the relay contains a reference which expressly refers to both the island dispute.

b. Reject the Indonesian argument that the disputed islands is an area under the control of the Netherlands based on the interpretation of Article IV of the Convention 1891. The Indonesian interpretation of the boundary $4^{\circ} 10 \mathrm{~N}$ intersecting P. Sebatik as an allocation line and continues eastward to touch The second disputed islands also unacceptable for the Court.

c. Clarity regarding the ownership status of those islands are also not included in the Memory van Toelichting. Memory Map van Toelichting that provides an illustration as Indonesia on the interpretation of Article IV is considered to be unenforceable for not being part of the 1891 convention.

d. the court also rejected the alternative proposition Indonesia since the two islands dispute is not mentioned in the contract agreements in 1850 and 1878 as part of the Sultanate of Bulungan submitted to the Dutch colonial government.

e. Mastery effectively considered as a problem that stands alone in the of 1999 as the critical date RI considering legal arguments and legal arguments Malaysia can not prove ownership of each claim over the islands in dispute settlement dispute to the International Court of Justice finally diserahakan this was essentially a the success of diplomacy on the part of Malaysia and Indonesia.

The way of peace pursued by Indonesia and Malaysia will provide great impact for the region, such as the way of solving the two sides (Malaysia-Indonesia) are leaving this issue completely to the International Court can be emulated as a model settlement of territorial claims of other inter- ASEAN member countries are still quite a lot going on, such as Malaysia and Thailand territorial claims with almost all its neighbors.

One thing to lament in the conflict resolution mechanism of Sipadan and Ligitan is not employed the ASEAN regional mechanisms. ASEAN, as a regional cooperation forum, a very minimal role in solving the border. This is because it is seen as a domestic issue and ASEAN countries do not intervene in it.

As a result of the fall of Sipadan and Ligitan to Malaysia hand domestic impact is not less great, a lot of comments and the notion that the State Department was the one major cause of the loss of Sipadan and Ligitan considering kepemiminan should the State Department under the Foreign Ministry. ${ }^{10}$

10, Sartono Kartodirdjo, Nationalism, Awareness and National Culture, Aditya Media, Yogyakarta, 1993 
In anticipation of the negotiations at a later stage, it is necessary to continue in-depth assessment to strengthen our bargaining position. A strong legal basis would be its capital base, but must be supported by excellence in the art of negotiation to convince the opponent.

For whatever reason, perangsebaiknya option is not used to prevent the recurrence of similar incidents, the Indonesian government must deal with more serious problems border regions and islands bordering neighboring countries. Just imagine to fight for Sipadan-Ligitan in the International Court of Justice should get out more than Rp16 billion fund.

And it's not the money a little more so to lose one island means a threat to the territorial integrity of Indonesia. This is important, because the disputed islands owned by Indonesia not only Sipadan-Ligitan, but many other islands. In addition, it can also be a bad precedent. ${ }^{11}$

\section{The attitude that should be taken by Indonesia to the future in a similar case}

To the accountability of the government to maintain the existence of the territorial integrity of experts of international law, loss of Sipadan and Lingitan in the International Court of Justice, being a very valuable lesson at all, it must be admitted that the government did not use the help of a lawyer or international legal expert from Indonesia, but experts from Department itself. Of the thousands of lawyers in Indonesia, according to Havas, yet none of them have the necessary skills to compete in the International Court of Justice. One is to strengthen and multiply the legal experts who mastered the knowledge of international law.

According to Director of Treaties on Political, Security and Territorial A airs Department, Arif Havas Oegroseno, Indonesia minimal people who are experts in the field of international law. However, should not the absence of international legal experts makes us insecure. Do not use a foreign lawyer because, in addition, he also found a lawyer in the country have a sense ofbelonging much higher compared to foreign lawyers. Meanwhile, the relative foreign lawyers see the case from the purely business side

The Malaysian government to build resorts parawisata new private company in Malaysia because Malaysia to understand the status quo as to remain under Malaysia until the dispute is completed, while the Indonesian side means that in this status means the status of the islands was not to be occupied / occupied until the issue of ownership of two islands this completed. 
On top of Sipadan island which covers only $4 \mathrm{~km} 2$, now, are waiting for tourists. Entrepreneurs Malaysia has increased the number of lodging to nearly 20 pieces. From the numbers, it does not tourism facilities can be called adequate.

But the Indonesian government, which was also felt to have the islands, immediately sent a protest to Kuala Lumpur, asked that construction be stopped there first.

The reason, Sipadan and Ligitan was still in dispute, not decided who owns it. In 1969, the Malaysian government unilaterally those islands into the national map

In 1976, the Treaty of Amity and Cooperation in Southeast Asia or TAC (Treaty of Amity and Cooperation in Southeast Asia) in the first KTT ASEAN in Island Bali among other states that will form the ASEAN High Council to resolve disputes between members of ASEAN but the Malaysian government refused reasonable because also involved a dispute with Singapore to claim island Batu Puteh, Ownership disputes Sabah the Philippines and disputes Spratley islands in South China Sea with Brunei Darussalam, Philippines, Vietnamese, Chinaand taiwan, Parties to Malaysia in 1991 and then put a squad of rangers (equivalent Brimob) expulsion of all citizens of Indonesia and the Indonesian request to retract a claim on both islands. ${ }^{12}$

After nearly 30 years of negotiations to arrive at a dead end, because both Indonesia are taking the position and arguments that both islands have become a part of its territory since the Dutch colonial period, and Malaysia also believes that sovereignty over the islands since the colonial British, fixed persist in their respective positions. In 1997 the two sides agreed to pursue legal action is to submit the dispute to the International Court of Justice. ${ }^{13}$

The attitude of the Indonesian side that wanted to bring this issue through the ASEAN High Council and always refused to carry this issue to ICJthen softened. During his visit to Kuala Lumpur on October 7, 1996, President Suharto finally agreed to the proposal of the Prime Minister Mahathir once suggested also by the Secretary of State Moerdiono and Deputy Prime Minister Anwar Ibrahim, Made the deal "Final and Binding," on May 31,1997, the two countries signed the agreement. Indonesia ratified on December 29, 1997 by Presidential Decree No. 49 of 1997 as well as Malaysia ratified on 19 November 1997.

12 Thomas Merilin LI, 2013, "the Judicial Review of Settlement Concerning Determination Sea Boundary Country", Lex et Societatis Journal, Volume I No. 2, April-June, 2013.

13 Booth, Ken, "Security in Anarchy: Utopian Realism in Theory and Practice ", International Affairs (Royal Institute of International Affairs 1944), Volume 67 No. 3, July 1991 


\section{CONCLUSION}

Settlement of disputes by Indonesia and Malaysia in determining sovereignty of Pulau Sipadan and Ligitan is a way of peaceful resolution of disputes, which Indonesia and Malaysia chose International Court of Justice to settle the dispute, the legal basis in the settlement of this dispute is Article 2, paragraph 3 and article 33 of the Charter. Dispute over the islands of Sipadan and Ligitan due to the vagueness of the borders created by the Netherlands and the United Kingdom is a country precursor of Indonesia and Malaysia in the east coast of the island of Borneo, so when Indonesia and Malaysia meet to define the border line between the two countries on the island of Borneo, this problem arises because the two sides were claimed over Sipadan and Ligitan. Various bilateral meetings conducted by the two countries in an effort to solving this dispute but the dispute can not be resolved, so that the two countries agreed to submit this dispute to the International Court of Justice. Various kinds of arguments and evidence juridical put forward the two sides in the trial at the International Court, and ultimately the International Court decided that sovereignty over Sipadan and Ligitan islands belonged to Malaysia on the basis of occupation, with Malaysia and the UK as the precursor more implementing effectiveness in Sipadan and Ligitan.

\section{BIBLIOGRAPHY}

Abdullah, Taufik, "Towards a National Historical Writing at the Local Level”, ed, Yogyakarta, Press UGM, 2005

Booth, Ken, "Security in Anarchy: Utopian Realism in Theory and Practice", International Affairs (Royal Institute of International Affairs 1944), Volume 67 No. 3, July 1991

Dhakidae, Daniel, “Relationship Love - Hate between Indonesia and Malaysia”, Jakarta .Prisma, 2009

Huala, Adolf , International Dispute Resolution Law, Jakarta,Sinar Grafika 2006

Pendekta 2006, Journal of Legal Studies State University of Semarang, “ International Studies Against Against Human Rights “, Volume 2 \# 2, July-December, 2008.

Thomas Merilin LI, 2013, the Judicial Review of Settlement Concerning Determination Sea Boundary Country, Lex et Societatis Journal, Volume I No. 2, April-June, 2013.

Wallensteen, Peter.. Understanding Conflict Resolution. London: Sage Publications, 2002 